\title{
TELEMARKETING AND THE DOOR TO DOOR SALES ACT 1967
}

\author{
Kate Tokeley*
}

The Door to Door Sales Act 1967 was intended to protect consumers from the sales pressure applied by sellers knocking on their door in an attempt to sell their products. In recent times sellers have adopted new methods of marketing their products, including the practice of telemarketing. In the recent case of Commerce Commission v Telecom Mobile Ltd the Court of Appeal concluded that the particular telemarketing activities undertaken by Telecom Mobile were covered by the Door to Door Sales Act 1967. This article analyses the difficulties and uncertainty of applying the outdated Act to the practice of telemarketing. Some contracts made as a result of telemarketing are covered by the Act and other contracts are not. The article argues that this arbitrary approach is unsatisfactory and that the law should be reformed so that the Act expressly covers all contracts that result from an unsolicited telemarketing phone call.

\section{INTRODUCTION}

In 2005 the Court of Appeal in Commerce Commission v Telecom Mobile Ltd concluded that the Door to Door Sales Act 1967 (the Act) covered the telemarketing practices carried out by Telecom Mobile. ${ }^{1}$ In that case it was found that the contract in question was not concluded until well after the telephone call, when the consumer received the product at home. The Court also discussed the applicability of the Act to telemarketing practices whereby a consumer enters into a contract on the telephone. It is this more common telemarketing scenario that is examined here. A consumer who makes a hurried decision to enter a contract over the phone is in a similar position to a consumer who agrees to make a purchase from a door to door salesperson. Both consumers are faced with a seller cold-calling their home. The issue is whether the consumer dealing with a telemarketer is entitled to the same level of legal protection as a consumer facing a door to door salesperson and, if not, whether they should be entitled to such protection.

* Senior Lecturer, Law Faculty, Victoria University of Wellington.

1 Commerce Commission v Telecom Mobile Ltd [2006] 1 NZLR 190 (CA) [Telecom Mobile (CA)]. The case was subsequently appealed to the Supreme Court but the question of the Act's applicability was no longer an issue. See below Part III A The Facts and Issues. 
This article concludes that the legal position in respect of telemarketing and the Act is unclear and unprincipled. It recommends that Parliament reform the Act so that it expressly provides consumers with cancellation rights for contracts formed in all telemarketing situations.

\section{THE DOOR TO DOOR SALES ACT 1967}

\section{A Policy Underpinnings of the Act}

In the course of the second reading of the Door to Door Sales Bill the following statement was made in respect of its purpose: ${ }^{2}$

The purpose of the Bill is to allow a purchaser who has signed an agreement involving a credit sale the right to cancel the sale if on mature consideration and perhaps discussion with other members of the

family, he or she feels that it is not in her interests to go on with the transaction.

Door to door selling places consumers in a particularly vulnerable position. The element of surprise results in a psychological disadvantage which might cause the consumer to enter into a contract that they would not normally enter into. The pressure of the selling technique means that the consumer has no time to reflect on the purchasing decision and has no opportunity to compare the seller's product with similar products offered by competitors. The Act gives the consumer a second chance to reflect on the contract and make a final decision without the salesperson in their house.

\section{B Key Provisions}

The Act is directed at suppliers who try to supply goods or services by approaching people in their own homes. The requirements of the Act apply wherever a "credit agreement" is made at a place other than "appropriate trade premises". ${ }^{3}$ A "credit agreement" is defined under section 2(1) as any credit sale agreement, hire purchase agreement or hiring agreement under which the vendor sells, lets, hires, or bails the goods that are the subject of the agreement in the vendor's ordinary course of business. This requirement for a credit element to the sale is arguably an unnecessary restriction as the pressure to enter a contract in a door to door situation is presumably the same whether or not the purchaser pays outright or enters into a credit agreement. Curiously, sections 3 and $3 \mathrm{~A}$ of the Act appear to make the credit element unnecessary in a contract for services. In

2 (14 November 1967) 354 NZPD 4215. The introduction of the Act arose out of a report of the Tariff and Development Board "Interim Report on Door-to-Door Selling of Books" [1968] IV AJHR H49 178. This report is referred to by the High Court in Commerce Commission v Telecom Mobile [2004] 3 NZLR 667, paras 83-85 (HC) France J [Telecom Mobile (HC)]. The Tariff and Development Board discussed concerns about sales techniques that resulted in "hurried decisions induced by pressure salesmanship" and recommended that customers should have "time for reflection before being irrevocably committed" (at 180 of the report).

3 See for example Door to Door Sales Act 1967, ss 5 and 7. 
practice there is generally a credit element in most service agreements anyway as the services are performed prior to payment.

The term "appropriate trade premises" is defined in section 2(1) in relation to the supply of goods as those premises where the vendor normally carries on business or where similar goods are normally offered or exposed for sale in the course of a business carried on at those premises. Similarly, in respect of services, the term "appropriate trade premises" is defined as premises at which the vendor or any bank, solicitor, or chartered accountant normally carries on business. There is no mention in the Act of the seller having to be at the buyer's home, which is the scenario characterised by the title of the Act.

The Act provides consumers faced with this type of selling method with legal protection in the form of a cooling-off period. Section 7 allows the consumer a period of seven days after the making of an agreement to cancel the contract by notice in writing. This provision overrides the normal rules of contract by allowing the consumer to cancel an otherwise valid contract. Furthermore, section 5 provides that a contract covered by the Act is unenforceable if the requirements of section 6 are not met. Section 6 requires that the seller disclose to the consumer the rights of cancellation in a written statement in accordance with the form set out in the first schedule of the Act. ${ }^{4}$

\section{AN OVERVIEW OF THE TELECOM MOBILE CASE}

\section{A The Facts and Issues}

Mainly Mobile (an agent of Telecom Mobile) embarked on telemarketing campaigns in 2001 and 2002 that sought to sell new mobile phones and telecom mobile network connections to existing users of Vodafone mobiles. Mainly Mobile made unsolicited phone calls and passed on to Telecom the names and numbers of people who responded positively to the call. Telecom then undertook a credit check on those people. If the credit check was acceptable, the packaged phones were dispatched together with a document containing Telecom Mobile's standard contractual terms. The terms committed the consumer to a 24 month contract that could only be cancelled on payment of a disconnection fee. The phones were contained in a box with a red seal. The instructions to the consumer stated that breaking the seal would constitute acceptance of the phone and contract. It also made it clear that the phone could only be returned if the box was unopened.

One of the main issues that arose in the High Court and the Court of Appeal was whether the Act could apply to the telemarketing practices of Telecom Mobile. If the telemarketing campaign was considered to fall within the ambit of the Act then Telecom Mobile had breached section 6 by failing to properly inform consumers of their rights of cancellation. The consumers were left with the impression that breaking the seal meant that they had accepted the phone and could not cancel the contract. If the Act applied, this was not the correct legal position. The consumers were in fact

4 See Door to Door Sales Act 1967, ss 5-6 and $1^{\text {st }}$ sch. 
entitled to a cooling-off period of seven days and this period applied whether or not they opened the box. Up to 22,000 consumers were affected.

The case was later heard in the Supreme Court but by that stage the question of the applicability of the Act was no longer in issue. ${ }^{5}$ Telecom had conceded that the Act applied and that it had breached section 6. It appealed on the basis that it had not breached section 12(2) of the Act, which allows consumers to recover money that they have paid in situations where the vendor has defeated, evaded, avoided or prevented the operation of the Act. The Supreme Court made no comments on the applicability of the Act to telemarketing situations. The arguments about the interpretation of section 12(2) are complicated and technical. There is no need to canvas them here as the focus in this article is on whether telemarketers have duties under the Act, rather than the exact extent of those duties.

\section{B Reasons Why the Act Applied to the Telecom Telemarketing Contracts}

Both the High Court and Court of Appeal concluded that the telephone discussions between Telecom Mobile and the customers were properly interpreted as mere initial steps towards the completion of a contract. ${ }^{6}$ The offer was not made until Telecom had approved the application after a favourable credit check and the acceptance was not made until the customer broke the seal on the telephone box. Telecom had waived the need for communication of the acceptance in accordance with the principles in the Carbolic Smoke Ball case. ${ }^{7}$ The contract was therefore formed at the time of acceptance at the customer's home. Since the customer's home is not "appropriate trade premises" the Act applied.

It was the specific facts of the Telecom Mobile case that allowed the High Court and Court of Appeal to say the contracts were not made on the telephone or at the call centre and that the Act therefore applied. The more significant question for telemarketers in general is whether the Act applies to contracts that are formed over the telephone, which is probably the more likely fact scenario in a conventional telemarketing situation. The Court of Appeal and High Court make some interesting obiter comments in respect of this issue. The remainder of this article attempts to resolve the matter.

5 Telecom Mobile Ltd v Commerce Commission [2006] 3 NZLR 323 (SC).

6 Telecom Mobile (CA), above n 1, para 37 William Young J for the Court; Telecom Mobile (HC), above n 2, para 33 France $\mathrm{J}$.

7 Carlill v Carbolic Smoke Ball Co [1893] 1 QB 256 (CA). 


\section{DOES THE ACT APPLY TO CONTRACTS MADE OVER THE PHONE?}

\section{A At What Place is the Contract Made?}

As has already been explained, the Act applies wherever a "credit agreement" is made at a place other than "appropriate trade premises". ${ }^{8}$ Therefore, the crucial question to resolve in a telemarketing scenario is where the contract is made.

In the case of Brinkibon Ltd $v$ Stahag Stahl und Stahlwarenhandels-gesellschaft MbH it was held that in situations where contracts are formed by means of instantaneous communication, such as telex or telephone, the contract is deemed to be concluded where and when the offeror receives notice of acceptance. ${ }^{9}$ The Court of Appeal expressed some concerns over the appropriateness of applying the Brinkibon case when interpreting the Act. These concerns are discussed below in Part VI A. At this stage it is useful to summarise the position if the principles of Brinkibon are applied.

According to the rule in Brinkibon, where the buyer is the offeree the contract will have been made at the place where the telemarketer receives notice of that acceptance over the phone. Conversely, if the telemarketer is the offeree then the contract will have been made at the customer's home when receiving notice of the telemarketer's acceptance over the phone.

\section{B Who is the Offeror and Who is the Acceptor?}

The rule in Brinkibon means that when determining where the contract is made it is first important to establish which party made the offer. In the Telecom Mobile case it was decided that it was the telemarketer who made the offer and the customer gave acceptance by breaking the sealed phone box. However, not all telemarketing situations will have the equivalent of the requirement that the customer break a sealed box in order to accept the offer. In addition, it will not always be the case that the phone conversation can be interpreted as merely an initial stage in negotiations. In many telemarketing campaigns the discussions over the phone will be far more definitive and it can be said that the contract has been made over the phone.

Whether it is the seller or buyer who makes the offer in these cases will depend on the individual circumstances of each case. The script of the telephone conversation would need to be examined. In some instances it might be the seller who takes the initial step of making an invitation to treat, followed by the buyer who makes an offer to purchase, which is subsequently accepted by the seller. In other cases it might be the buyer who makes an invitation to treat when showing a willingness to negotiate, and then the seller makes an offer which is accepted by the buyer. The law requires that for a statement to be an offer it must show an intention on the part of the maker of the statement to

8 See above Part II The Door to Door Sales Act 1967.

9 Brinkibon Ltd v Stahag Stahl und Stahlwarenhandels-gesellschaft MbH [1983] 2 AC 34 (HL) [Brinkibon]. See also Entores Ltd v Miles Far East Corporation [1955] 2 QB 327 (CA). 
be bound on defined terms immediately upon acceptance. ${ }^{10}$ In many telemarketing cases it is likely to be the seller that makes the offer on the phone when they show a readiness to undertake the obligation to sell on certain terms. The customer is then left to either accept or refuse this offer.

\section{What are "Appropriate Trade Premises"?}

The next step is to establish whether or not the place where the contract is made can be considered "appropriate trade premises". The term "appropriate trade premises" is defined in section 2(1) as premises where the vendor normally carries on business. In respect of the supply of goods it also includes premises where similar goods are normally offered or exposed for sale in the course of a business carried on at those premises. In a case where the contract is concluded at a customer's home when the customer receives notice of the telemarketer's acceptance, the contract would clearly be covered by the Act because the customer's home does not fit within the definition of "appropriate trade premises".

When the contract is made at the place where the telemarketer makes the phone call, the legal position is less obvious. The exact nature of the place where the telemarketer makes the phone call will be different in any given case. Some vendors might conduct a significant proportion of their business via telemarketing and have a dedicated call centre set up for conducting telemarketing campaigns. In this situation it is not clear whether the call centre should be considered a place where the vendor normally carries on business. On the one hand, they are not premises where the vendor exposes goods for sale or makes face to face offers to sell. No-one can pay for and take possession of the goods from such a call centre. On the other hand, the vendor does normally carry on the business of selling their goods or services over the phone from these premises. It might also offer similar goods for sale during some phone calls.

In the Telecom Mobile case the call centre happened to also be retail premises operated by Mainly Mobile. It was therefore a place where the vendor normally carried on the business of selling their goods. The High Court reasoned that if the contract had been made over the phone, then the contract would have been made at the call centre, which was "appropriate trade premises" and therefore the Act would not apply. ${ }^{11}$

A different fact scenario might involve a vendor conducting a one-off more limited telemarketing campaign from random locations. For example, some calls might be made from the vendor's shop ("appropriate trade premises") and some calls might be made from home (not "appropriate trade premises").

10 See for example Morton-Jones v R B and J R Knight [1992] 3 NZLR 582, 587 (HC) Doogue J.

11 Telecom Mobile (HC), above n 2, para 32 France J. 


\section{DIFFICULTIES IN APPLYING THE ACT TO TELEMARKETING}

The above examples highlight the difficulty of applying the Act to a contract made as a result of a telemarketing campaign. A formal application of contract principles of offer and acceptance, and interpretation of the term "appropriate trade premises", results in the consumer's level of legal protection depending on two seemingly irrelevant matters. First is the somewhat artificial and arbitrary assessment of which party is the offeror. In some cases this assessment could simply be the result of slightly different wording in a telemarketer's phone script. Second is the equally fickle matter of where the telemarketer happens to be making the phone call from.

These two factors, which appear central to an analysis of the application of the Act, do not have any bearing on the policy reasons behind the Act. The Act is designed to give legal protection to consumers who rush to enter into a contract in situations where pressure sales tactics are employed. The questions of which party is the acceptor and where the telemarketer is when making the phone call do not seem in any way relevant to this purpose of consumer protection. There is no sound policy reason why a consumer who accepts an offer over the phone from a telemarketer located in retail premises should not be protected by the Act when a consumer who makes an offer over the phone which is accepted by a telemarketer is protected by the Act.

Of course the above difficulties do not arise when asking the same questions in relation to a traditional door to door sale. In a door to door sale, no matter which party is the offeree, the contract is made at the customer's home. The home can never be considered "appropriate trade premises", and therefore the consumer is always covered by the Act.

\section{OPTIONS FOR RESOLVING THESE DIFFICULTIES WITHIN THE FRAMEWORK OF THE ACT}

\section{A Presume that Contracts Made over Phone are Covered by the Act}

In the Telecom Mobile case the Court of Appeal pointed out the incongruity of allowing the location of the telemarketer to influence the application of an Act that is designed to protect consumers: ${ }^{12}$

\footnotetext{
On the Telecom Mobile case, much rests on the coincidence that the call centre from which the Mainly Mobile telemarketing campaign was conducted happened to be part of retail premises operated by Mainly Mobile and its associated company. In the context of the consumer protection orientated Door to Door Sales Act, it is difficult to see how this consideration (of which consumers are necessarily ignorant) can genuinely bear the weight placed on it by Telecom Mobile.
}

The Court of Appeal also questioned the relevance of the Brinkibon case to the Act. ${ }^{13}$ The Court in the Brinkibon case had to decide where the contract was made in order to decide if it was "made

12 Telecom Mobile (CA), above n 1, para 43 William Young J for the Court. 
within the jurisdiction" for the purposes of determining whether the proceedings could be served outside of the jurisdiction. ${ }^{14}$ The case was not dealing with consumer protection legislation.

The Court of Appeal suggested that a viable solution to these dilemmas would be to simply presume that all sales made over the phone by virtue of a telemarketing campaign where customers are cold called at their home are made at a place other than "appropriate trade premises" when the customer views the contract as having been made from home. ${ }^{15}$ The presumption should apply even if the telemarketer is ringing from a shop. These comments were, of course, obiter because the facts of the Telecom Mobile case could be resolved without making a decision on the relevance of the telemarketer's location when making the phone call. The Court's analysis presumably rests on the assumption that Brinkibon should not be applied and that the contract should be taken as having been made at the consumer's home if that is what the customer perceives the situation to be, regardless of whether it is the consumer or telemarketer that is the offeror.

Although it may seem tempting to ignore the principles established in Brinkibon where they do not produce a sensible result, this approach has its drawbacks. The questions of where and when a contract is made may be relevant in several different areas of the law. As has been pointed out, the Brinkibon case needed to answer these questions in an area of law unrelated to consumer protection. Yet to suggest that the law should treat a contract as having been made at a different place and different time depending on the area of law at issue seems illogical. It is also somewhat arbitrary to suggest that the customer's perception of where the contract has been formed should be the decisive factor in determining where the contract is formed for the purposes of the Act. This renders the notion of where a contract is formed a wholly subjective matter. Without a definitive, objective answer as to where and when a contract is concluded there would be great uncertainty in the business world and a degree of fiction about contract formation.

The reason that applying Brinkibon in the case of the Act leads to an unsatisfactory result is not because there are flaws in the reasoning of Brinkibon or because the Brinkibon rules should not apply to consumer protection cases. The reason is that the wording of the Act requires an answer to the question of where the telemarketing contract is made. In the context of consumer protection in telemarketing campaigns this question ought to be irrelevant. If the Act is designed to protect consumers entering sales contracts over the phone as a result of a telemarketing campaign, then it should be enough to show that the contract is made over the phone. It is not useful to analyse whether the contract was made at the premises of the consumer or telemarketer.

13 Telecom Mobile (CA), above n 1, para 42 William Young J for the Court.

14 Telecom Mobile (CA), above n 1, para 42 William Young J for the Court.

15 Telecom Mobile (CA), above n 1, para 44 William Young J for the Court. 
It is arguable that in the context of a contract made over the telephone, the question of where the contract is made is never appropriate. The parties to the contract probably do not see themselves as having made the contract in any one place but rather in the no man's land of "over the phone". Policy-makers dealing with contracts made over the telephone might be wise to consider what policy concerns are relevant to the drafting of a particular law and attempt to frame the relevant issues without reference to "where" the contract is made.

\section{B Purposive Approach}

A further option for resolving the question of whether the Act applies to telemarketing is to employ the purposive approach to statutory interpretation. Section 5(1) of the Acts Interpretation Act 1999 states that "the meaning of an enactment must be ascertained from its text and in light of its purpose."

In the High Court the Commerce Commission argued that because telemarketing involves cold calling customers in their own home, it is a sales technique that falls within the policy or purpose of the Act and that therefore customers should be protected by the Act. ${ }^{16}$ The Commission pointed out that even if telemarketing might not have been contemplated by the drafters in 1967, the ambulatory approach to statutory interpretation should be applied so that the Act is interpreted sufficiently broadly to cover telemarketing, a modern approach to cold calling. ${ }^{17}$ This view is supported by academic commentators who have argued that: ${ }^{18}$

Under the purposive approach to statutory interpretation, it is difficult to see how the practice of telemarketing could be used to circumvent Parliament's very clear objective of protecting consumers against unsolicited selling of credit agreements in consumers' houses.

These comments presuppose that it is appropriate to use the purposive approach to interpret the relevant provisions of the Act. The purposive approach should, however, only be applied where there is ambiguity in the words of the statute. If the words are clear then the court must apply the words as they stand. In addition, the purposive approach should only be used to employ a meaning that the words of the statute are reasonably capable of bearing. The words of the Act must be examined to establish whether, in any given case, there is any ambiguity.

16 Telecom Mobile (HC), above n 2, para 23 France J.

17 Telecom Mobile (HC), above n 2, para 22 France J. Note that the ambulatory approach to statutory interpretation is encapsulated in section 6 of the Acts Interpretation Act 1999, which states that "enactments apply to circumstances as they arise".

18 A Sims and L Miller "Door to Door Sales Act in the $21^{\text {st }}$ Century" [2005] NZLJ 393, 396. 


\section{Ambiguity}

The discussion so far has suggested that, although the wording of the Act sits uncomfortably with the telemarketing sales technique, this is not always due to any ambiguity in the wording. Consider the position of a telemarketer who makes a cold call from retail premises in a situation where the telemarketer can be said to be the offeror. In this situation, so long as the usual rules of contract formation are followed, the contract has been made at the telemarketer's retail premises, which are clearly "appropriate trade premises". The Act therefore does not apply to the sale. Unless it can be said that the concept of where the contract is "made" is ambiguous in the context of telemarketing, there is no reason to consider Parliament's purpose. ${ }^{19}$ Even if Parliament had intended that the Act apply to these telemarketing sales, the language of the Act does not permit this. The Courts should not use the purposive approach to make a law consistent with Parliamentary intent if Parliament has failed to state that intent in the statute. As Sir Ian McKay has stated: "A purposive approach should not be made an excuse for starting with the underlying purpose, and then forcing the words into a preconceived and strained construction to fit that assumption." 20

There are, however, some telemarketing situations which do reveal a degree of ambiguity in the provisions of the Act. In these cases it may be useful to consider purpose in order to ascertain meaning. For example, as discussed above in Part IV C, it is not clear whether a call centre from which a telemarketer habitually makes telemarketing sales agreements over the phone but which is not retail premises should be considered "appropriate trade premises". If it can be shown that Parliament intended to cover telemarketing practices, the courts might decide to interpret "appropriate trade premises" as excluding these call centres. This would give consumers in this situation the protection of the Act regardless of which party's premises the contract is made at because neither the consumer's home nor the call centre would be considered "appropriate trade premises". However, care must be taken when assessing whether Parliament did in fact intend to protect consumers from telemarketers. Parliamentary purpose may be ascertained from the wording of the Act, extrinsic aids and consideration of the mischief that the Act is aiming to remedy. These are each discussed in turn.

\section{Wording of the Act}

The wording of the Act does not comfortably fit the situation of a contract made over the telephone. The Act (both in the long title and in its provisions) refers to contracts entered into at places other than "appropriate trade premises." It therefore requires consideration of where the

19 In the context of a telephone sale it could be argued that reference to where a contract is "made" is ambiguous because is not clear whether it means the agreement is "made" in no man's land over the telephone, or at both the offeror's and acceptor's premises, or that normal rules of contract formation should be applied so that it can be said that the contract is "made" at the place where the offeror receives notification of acceptance.

20 Sir Ian McKay "Interpreting Statutes - A Judges View" (2000) 9 Otago LR 743, 749. 
contract is made. This requirement poses no difficulties when the contract is made with a salesperson who is physically present in the customer's home or at a private house where the customer is visiting or staying. However, in the case of telemarketing the issue of where the contract is made becomes problematic. The discussion above illustrates these difficulties, not the least of which is that some telemarketing contracts are covered by the Act and some are not, despite the customer being equally vulnerable in each case. The arbitrariness of the Act's coverage of telemarketing indicates that Parliament did not in fact intend to incorporate telemarketing.

If Parliament had intended the Act to cover telemarketing it would have been far less confusing to have simply stated that the Act also applies to contracts made during the course of an unsolicited telephone conversation with a telemarketer. The fact that the Act does not at any point mention the concept of telemarketing (even the title "Door to Door Sales Act" is very specific) again suggests that Parliament did not contemplate telemarketing when drafting the Act. A 1992 Consumer Affairs discussion document on the Act concluded that: ${ }^{21}$

The Door to Door Sales Act was originally intended to regulate agreements made by sellers moving from house to house and was drafted with an eye on the kinds of devices which might be used to avoid it. As a result the Act applies to many transactions which were never contemplated at the time of its enactment.

It is perhaps merely fortuitous that the wording of the Act covers some telemarketing situations.

\section{Extrinsic aids}

Alongside the purposive approach has come the acceptance of the use of extrinsic material such as the Hansard debates to assist in determining Parliamentary purpose. ${ }^{22}$ In the case of the Act, the Hansard debates and the policy report recommending it do not mention the practice of telemarketing. ${ }^{23}$ The discussions are based solely on the need to protect consumers from the pressure associated with door to door sales.

\section{Mischief to be remedied by the Act}

In its broadest sense the Act might be stated as having the purpose of protecting consumers from the mischief of sellers cold calling their homes in order to sell goods. It could be argued that in order to tackle this larger mischief the courts should interpret the Act broadly so that it covers telemarketing, which is simply a more modern approach to cold calling. In other words, it should not matter whether the cold call is a knock at the door or the telephone ringing.

21 See the Executive Summary of Ministry of Consumer Affairs Discussion Paper on Direct and Distance Selling (Wellington, 1992) para 1.2.

22 See Marac Life Insurance Ltd v Commissioner of Inland Revenue [1986] 1 NZLR 694, 701 (CA) Cooke J.

23 See for example (14 November 1967) 354 NZPD 4215 and Tariff and Development Board, above n 2. 
For this argument to be successful it must be shown that telemarketing presents the same policy concerns as door to door selling. Telemarketing, like door to door selling, puts the consumer in a pressure type situation, being faced with a cold call into their home. However, the pressure of a telephone call is somewhat less than the pressure of someone standing on the doorstep. It is probably psychologically easier to hang up the phone than it is to shut the door on someone. There is, admittedly, a degree of pressure and there is the possibility that the consumer might enter into a purchase they would not otherwise have entered. In addition, the consumer is not only unable to compare the product with other products, they cannot even see the product that they are agreeing to purchase. Nevertheless, despite some good reasons for extending protection to telemarketing, the policy fit is not exact. In view of this, the fact that the extrinsic aids do not mention telemarketing and that the wording of the Act works so poorly when applied to telemarketing, the argument that Parliament intended the Act to cover telemarketing is weak.

\section{Conclusion on purposive approach}

In summary, the purposive approach is of limited assistance in determining whether the Act applies to telemarketing. In many situations the wording of the Act is unambiguous and should be applied without reference to purpose. In other situations where the Act is arguably ambiguous (for example, it is not clear whether call centres are "appropriate trade premises") the purposive approach is difficult to employ because it is not clear that Parliament's purpose was to cover telemarketing practices.

\section{REFORM OF LAW TO SPECIFICALLY INCLUDE TELEMARKETING}

Coverage of telemarketing under the Act is unsatisfactory because it is either unclear or based on what ought to be irrelevant distinctions. This leaves telemarketers uncertain of whether the Act applies to their activities and consumers unsure of their rights. Some telemarketers and consumers may automatically assume that the Act does not apply to them because the title and the wording of the Act do not mention telemarketing. The law is in need of urgent reform to remove these uncertainties and to remove the current arbitrariness of a telemarketer's position under the Act.

There are good arguments to support the proposition that consumers who are subject to a telemarketing campaign are in a similarly vulnerable position to those consumers who are faced with a door to door sales person and are therefore equally deserving of legal protection. They too are liable to make a hurried decision under pressure with no opportunity to view other similar products or to even see the product that they are agreeing to purchase. Although it could be argued that the principle of "buyer beware" should apply, it seems unfair to allow a consumer who enters into a door to door contract a right of cancellation and yet deny this right to the consumer in a telemarketing situation. The law should therefore be reformed so that it expressly provides consumers with cancellation rights when they enter into a contract over the phone as a result of a cold call from a telemarketer. 
Such a reform could either involve redrafting the Act to specifically include telemarketing or enacting a new statute dealing only with telemarketing. Redrafting the current Act could be done by adding in a provision that the Act applies to contracts made during the course of an unsolicited phone conversation with a telemarketer. It would make sense to change the name of the Act to include the word "telemarketing".

Consideration could also be given to including contracts made via email as a result of an unsolicited email marketing of a product (often referred to as spam). The Act is likely to pose the same interpretation difficulties when applied to spam as it does when applied to telemarketing. It is arguable that consumers who enter into contracts via email after receiving an unsolicited email from a seller should be protected by a cooling-off period in the same way as consumers entering into a door to door sale. However, an email does not perhaps impose the same degree of pressure on a consumer as a person on the doorstep. As technology changes, more methods of cold calling consumers may emerge. For example, selling goods via text messaging could become prevalent. Detailed consideration of email spam and other technologies are beyond the scope of this paper but it is important to flag the idea of rewriting the Act so that its overarching principle is to provide a cooling-off period to all consumers in cold call situations at home, regardless of the communication technology that is used by the seller.

\section{CONCLUSION}

The Door to Door Sales Act was enacted in 1967 when the most common form of cold call selling was door to door selling. The Act does not mention telemarketing specifically and this method of selling was almost certainly never contemplated by Parliament at the time of drafting the Act.

The Telecom Mobile case highlights the difficulties and uncertainties that result from attempting to apply the outdated Act to the practice of telemarketing. The wording of the Act inadvertently results in some telemarketing situations being covered. However, the telemarketing consumers who are protected by the Act are no more worthy of protection than those telemarketing consumers who are not covered. The law should be reformed so that it establishes a consistent, clear and principled approach to telemarketing. This article has suggested that the legal protection given to consumers in door to door sales should be expressly extended to all consumers who enter into a contract as a result of an unsolicited telemarketing phone call. 
